\title{
Protective effects of rosmarinic acid against hydrogen peroxide-induced cellular senescence and the inflammatory response in normal human dermal fibroblasts
}

\author{
HYUNG JIN HAHN ${ }^{1}$, KI BBEUM KIM ${ }^{2,3}$, IN-SOOK AN ${ }^{2}$, KYU JOONG AHN ${ }^{1 *}$ and HYUN JOO HAN ${ }^{3 *}$ \\ ${ }^{1}$ Department of Dermatology, Konkuk University School of Medicine, Seoul 05030; \\ ${ }^{2}$ GeneCellPharm Corporation, Seoul 05836; ${ }^{3}$ Department of Biological Engineering, \\ Graduate School of Engineering, Konkuk University, Seoul 05029, Republic of Korea
}

Received August 16, 2016; Accepted August 23, 2017

DOI: $10.3892 / \mathrm{mmr} .2017 .7804$

\begin{abstract}
Hydrogen peroxide $\left(\mathrm{H}_{2} \mathrm{O}_{2}\right)$ is a reactive oxygen species (ROS) that induces numerous cellular events, including cellular senescence and inflammatory responses. Therefore, the aim of this study was to investigate the protective effect of Rosmarinic acid (RA) in $\mathrm{H}_{2} \mathrm{O}_{2}$-induced oxidative stress in normal human dermal fibroblasts (NHDFs). Cytotoxicity assays were performed using a water-soluble tetrazolium salt, and senescence-associated $\beta$-galactosidase activity was determined to investigate the proportion of senescent cells. Antioxidant capacities were evaluated via $\mathrm{H}_{2} \mathrm{O}_{2}$-scavenging activity, reverse transcription-quantitative polymerase chain reaction, NRF2 luciferase reporter gene activity and intracellular ROS scavenging assays. Cytokine-coded gene expression analysis and nuclear factor- $\kappa \mathrm{B}$ luciferase activity were determined to verify the anti-inflammatory effect of RA. As a result, the present study demonstrated that rosmarinic acid inhibited $\mathrm{H}_{2} \mathrm{O}_{2}$-induced oxidative stress and inflammatory responses in normal human dermal fibroblasts. Initially, the doses of RA that exerted minimal cytotoxic effects in NHDFs were determined using a cytotoxicity assay. Subsequently, pretreatment with the appropriate doses of RA significantly reversed the $\mathrm{H}_{2} \mathrm{O}_{2}$-induced decrease in NHDF cell viability and decreased cellular senescence of NHDFs. In addition,
\end{abstract}

Correspondence to: Professor Kyu Joong Ahn, Department of Dermatology, Konkuk University School of Medicine, 120 Neungdong-ro, Gwangjin-gu, Seoul 05030, Republic of Korea E-mail:kjahn@kuh.ac.kr

Dr Hyun Joo Han, Department of Biological Engineering, Graduate School of Engineering, Konkuk University, 120 Neungdong-ro, Gwangjin-gu, Seoul 05029, Republic of Korea

E-mail:bonamie@hanmail.net

*Contributed equally

Key words: hydrogen peroxide, inflammatory response, oxidative stress, dermal fibroblasts, rosmarinic acid
RA inhibited $\mathrm{H}_{2} \mathrm{O}_{2}$-induced ROS production in NHDFs, as determined by a ROS scavenging assay. The protective effects of RA were mediated by the inhibition of nuclear factor erythroid-derived 2-like 2, a transcription factor that functions as a key regulator of redox sensitivity. Furthermore, RA suppressed $\mathrm{H}_{2} \mathrm{O}_{2}$-induced inflammation in NHDFs and significantly rescued $\mathrm{H}_{2} \mathrm{O}_{2}$-induced downregulation of sirtuin 1 . RA also inhibited nuclear factor (NF) $-\kappa \mathrm{B}$ transcriptional activity and the expression of $\mathrm{NF}-\kappa \mathrm{B}$ target genes, including tumor necrosis factor- $\alpha$ and interleukin- 6 , in $\mathrm{H}_{2} \mathrm{O}_{2}$-exposed NHDFs. Taken together, these data indicate that RA inhibits $\mathrm{H}_{2} \mathrm{O}_{2}$-induced cellular damage in NHDFs.

\section{Introduction}

The term reactive oxygen species (ROS) refers to all chemically reactive molecules containing an oxygen atom, including oxygen radicals and non-radicals. The various types of ROS are classified as either endogenous mitochondrial factors or extracellular factors (1). Hydrogen peroxide $\left(\mathrm{H}_{2} \mathrm{O}_{2}\right)$ is a reactive byproduct of the electron transport chain in mitochondria (1).

The skin is the largest organ of the body; it surrounds the body and protects it from the external environment. Extrinsic stimuli, including ultraviolet (UV) light, pollution and thermal stress, disrupt skin cell metabolism, thereby disrupting redox state equilibrium (2). Although cells employ efficient enzymatic and nonenzymatic antioxidant mechanisms, excessive ROS production can induce lipid peroxidation, DNA damage and protein denaturation (1). Proteins associated with conventional enzyme-mediated antioxidant mechanisms include superoxide dismutase (SOD), glutathione peroxidase and catalase (CAT) (1). These enzymes are primarily activated in response to ROS. In $\mathrm{H}_{2} \mathrm{O}_{2}$-exposed normal human dermal fibroblasts (NHDFs), excessive ROS production disrupts antioxidant defense mechanisms and induces the inflammatory response $(1,3)$.

In its inactive form in the cytoplasm, nuclear factor erythroid-derived 2-like 2 (NRF2) interacts with Kelch-like-ECH-associated protein 1 (4). A disruption in this interaction by factors, including ROS, activates the NRF2 signaling pathway (4). Activated NRF2 translocates to the 
nucleus where it binds to antioxidant response element (ARE), and initiates the transcription of genes associated with the response to oxidative stress, including heme oxygenase-1 (HO- 1$)$, SOD and CAT (5-7).

The mammalian Sir2 ortholog, sirtuin 1 (SIRT1), is a histone deacetylase that targets histones and nonhistone substrates, including nuclear factor $(\mathrm{NF})-\kappa \mathrm{B}$ and p53 $(8,9)$. Previous studies have demonstrated that SIRT1 is associated with the regulation of numerous cellular processes, including inflammation, apoptosis and autophagy (10-12). Under conditions of adaptive stress, including hypoxia, infection and caloric restriction, SIRT1 inhibits the proinflammatory cytokine $N F-\kappa B$ (13). NF- $\kappa$ B serves a dominant role in inducing the inflammatory response $(14,15)$. In response to excessive cellular stress, activated $\mathrm{NF}-\kappa \mathrm{B}$ directly activates the expression of genes encoding key inflammatory cytokines, including interleukin (IL)-6 and tumor necrosis factor (TNF)- $\alpha$ (16).

The use of the plant secondary metabolite rosmarinic acid (RA) has been studied in pharmaceutical and dietary supplements in Alzheimer's disease, atopic dermatitis and cardiovascular disease (17-21). Previous research has revealed that the effects of RA in these contexts are mediated by its antioxidant properties. One report demonstrated that the antioxidant activity of RA is able to inhibit UV-induced damage in the skin of mice (22). In addition, RA may protect human melanoma cells from $\mathrm{H}_{2} \mathrm{O}_{2}$-induced oxidative stress (23). Other reports have also demonstrated that RA protects human keratinocyte $\mathrm{HaCaT}$ cells from UVB-induced oxidative stress $(24,25)$. However, the effects of RA on NHDFs, which are the key mediators of skin firmness and elasticity, remain unclear. The present study aimed to investigate the effects of RA on $\mathrm{H}_{2} \mathrm{O}_{2}$-exposed NHDFs.

\section{Materials and methods}

Cell culture and treatment. NHDFs (Lonza Group, Ltd., Basel, Switzerland) and the NF- $\kappa$ B Luciferase Reporter NIH3T3 Stable Cell Line (Signosis, Inc., Santa Clara, CA, USA) were cultured in Dulbecco's modified Eagle's medium (Thermo Fisher Scientific, Inc., Waltham, MA, USA) supplemented with $10 \%$ fetal bovine serum (Sigma-Aldrich; Merck KGaA, Darmstadt, Germany) and $1 \%$ penicillin/streptomycin (Thermo Fisher Scientific, Inc.) at $37^{\circ} \mathrm{C}$ in an atmosphere containing $5 \% \mathrm{CO}_{2} . \mathrm{H}_{2} \mathrm{O}_{2}$ (Sigma-Aldrich; Merck KGaA) was diluted in phosphate-buffered saline (PBS) to obtain a $1 \mathrm{M}$ stock solution. For the $\mathrm{H}_{2} \mathrm{O}_{2}$ treatment experiments, the $\mathrm{H}_{2} \mathrm{O}_{2}$ stock solution was diluted in cell culture media at the indicated concentrations. RA (Sigma-Aldrich; Merck KGaA) was dissolved in dimethyl sulfoxide (Sigma-Aldrich; Merck KGaA).

Cell viability assay. Cytotoxicity was evaluated using a water-soluble tetrazolium salt (WST-1) assay (EZ-Cytox Cell Viability Assay kit; Itsbio, Seoul, Korea). NHDFs were seeded on 96 -well culture plates at a density of $3 \times 10^{3}$ cells and were incubated for $24 \mathrm{~h}$, at $37^{\circ} \mathrm{C}$. Subsequently, the cells were incubated with RA $(0-50 \mu \mathrm{M})$ for $12 \mathrm{~h}$, after which the cytotoxicity of RA was assessed. To examine the effects of RA against $\mathrm{H}_{2} \mathrm{O}_{2}$-induced cytotoxicity, NHDFs were incubated with the indicated concentration of RA (10, 20 and
$30 \mu \mathrm{M})$ for $12 \mathrm{~h}$ prior to $\mathrm{H}_{2} \mathrm{O}_{2}$ treatment. After $12 \mathrm{~h}, 600 \mu \mathrm{M}$ of $\mathrm{H}_{2} \mathrm{O}_{2}$ was added and incubated at $37^{\circ} \mathrm{C}$ for $2 \mathrm{~h} .1 / 10$ volume of WST-1 solution was then added to each well, and the cells were incubated at $37^{\circ} \mathrm{C}$ for $1 \mathrm{~h}$. Cell viability was evaluated by measuring absorbance at $450 \mathrm{~nm}$ using an iMark microplate reader (Bio-Rad Laboratories, Inc., Hercules, CA, USA).

$\mathrm{H}_{2} \mathrm{O}_{2}$ scavenging activity assay. The $\mathrm{H}_{2} \mathrm{O}_{2}$ scavenging activity of RA was evaluated as previously described (26). A solution containing $\mathrm{H}_{2} \mathrm{O}_{2}$ (40 mM in distilled water, $\mathrm{pH}$ 7.4) and varying concentrations of RA $(0-1 \mathrm{mg} / \mathrm{ml})$ was incubated at room temperature for $10 \mathrm{~min}$. Scavenger activity was subsequently assessed by measuring the absorbance of the $\mathrm{H}_{2} \mathrm{O}_{2} / \mathrm{RA}$ solution at $230 \mathrm{~nm}$ using a UV spectrophotometer (Shimadzu Corporation, Kyoto, Japan). A solution lacking $\mathrm{H}_{2} \mathrm{O}_{2}$ was used as a control, and L-ascorbic acid was used as the experimental control treatment. The experiments were conducted in triplicate at each concentration of RA. Scavenger activity was calculated using the following formula: $\mathrm{H}_{2} \mathrm{O}_{2}$ scavenging activity $(\%)=(1-$ sample/control $) \times 100$.

Intracellular ROS scavenging assay. Intracellular ROS production was evaluated using a 2'7'-dichlorofluorescein diacetate (DCF-DA; Sigma-Aldrich; Merck KGaA) staining assay. Briefly, cells were incubated with DCF-DA solution $(100 \mu \mathrm{M})$ at $37^{\circ} \mathrm{C}$ for $1 \mathrm{~h}$, after RA and $\mathrm{H}_{2} \mathrm{O}_{2}$ treatment. ROS levels were then analyzed using flow cytometry. The proportion of fluorescence-positive cells was measured using a FACSCalibur flow cytometer (BD Biosciences, San Diego, CA, USA) with excitation and emission filters of 488 and $530 \mathrm{~nm}$, respectively. $N$-acetyl-cysteine (NAC), ROS scavenger used as a positive control, was purchased from Sigma-Aldrich; Merck KGaA.

$N F-\kappa B$ luciferase reporter assay. The NF- $\kappa \mathrm{B}$ luciferase reporter assay was conducted as previously described (27) with some modifications. Briefly, NF- $\kappa$ B reporter NIH3T3 cells were seeded in 12-well cell culture plates at a density of $2 \times 10^{5}$ cells/well. After $24 \mathrm{~h}$ incubation, cells were pretreated RA for $12 \mathrm{~h}$ at 10,20 and $30 \mu \mathrm{M}$, and were then treated with $600 \mu \mathrm{M} \mathrm{H}_{2} \mathrm{O}_{2}$ for $2 \mathrm{~h}$. At the end of the experiments, the cells were resuspended in Passive Lysis Buffer (Promega Corporation, Madison, WI, USA). Subsequently, luciferin (Sigma-Aldrich; Merck KGaA) was added to the cells, and luciferase activity was measured using a Veritas luminometer (Turner Designs, Sunnyvale, CA, USA). The luciferase activity was normalized to $\beta$-galactosidase $(\beta$-gal) activity, and relative activity is presented as the percentage activity of the control with standard deviation. The results represent the mean of three independent experiments.

Senescence-associated $\beta$-gal (SA- $\beta$-gal) activity. $\beta$-gal expression was used as a marker of senescence (28). $\beta$-gal expression levels were determined using an SA- $\beta$-gal staining kit (Biovision, Inc., Milpitas, CA, USA) according to the manufacturer's instructions. NHDFs were seeded at a density of $1 \times 10^{6}$ cells/well in $60-\mathrm{mm}$ cell culture plates and were incubated until cell confluence reached $90 \%$. Later, cells were pretreated RA for $12 \mathrm{~h}$ at 10,20 and $30 \mu \mathrm{M}$, and were then treated with $600 \mu \mathrm{M} \mathrm{H}_{2} \mathrm{O}_{2}$ for $2 \mathrm{~h}$. After treatment, the cells 
Table I. Primer sequences for quantitative polymerase chain reaction.

\begin{tabular}{llll}
\hline Gene name & Gene symbol & \multicolumn{1}{c}{ Forward (5'-3') } & Reverse (5'-3') \\
\hline Superoxide dismutase 1 & SOD1 & GGGAGATGGCCCAACTACTG & CCAGTTGACATGCAACCGTT \\
Catalase & CAT & ATGGTCCATGCTCTCAAACC & CAGGTCATCCAATAGGAAGG \\
Sirtuin 1 & SIRT1 & GCAGGTTGCGGGAATCCAA & GGCAAGATGCTGTTGCAAA \\
Tumor necrosis factor- $\alpha$ & $T N F$ - $\alpha$ & CCCAGGGACCTCTCTCTAATC & GGTTTGCTACAACATGGGCTACA \\
Interleukin-6 & $I L-6$ & TAACAGTTCCTGCATGGGCGGC & AGGACAGGCACAAACACGCACC \\
Actin, beta & $\beta$-actin & GGATTCCTATGTGGGCGACGA & CGCTCGGTGAGGATCTTCATG \\
\hline
\end{tabular}

were washed in PBS and incubated in $0.5 \mathrm{ml}$ fixative solution (4\% formaldehyde, $0.5 \%$ glutaraldehyde in PBS buffer, $\mathrm{pH} 7.2$ ) for $10 \mathrm{~min}$ at room temperature. The fixed cells were incubated in a staining solution mixture [staining solution $(470 \mu \mathrm{l})$, staining supplement $(5 \mu \mathrm{l})$ and $20 \mathrm{mg} / \mathrm{ml} \mathrm{X-Gal} \mathrm{in} \mathrm{dimethylfor-}$ mamide $(25 \mu \mathrm{l})]$ for $24 \mathrm{~h}$ at $37^{\circ} \mathrm{C}$. Subsequently, $70 \%$ glycerol $(1 \mathrm{ml})$ was added to the cells and blue SA- $\beta$-gal-positive cells were counted under a microscope (Olympus IX51; Olympus Corporation, Tokyo, Japan).

$R N A$ isolation and reverse transcription-quantitative polymerase chain reaction ( $R T-q P C R)$ analysis. Before RNA extraction, cells were treated with RA $(10,20$ and $30 \mu \mathrm{M})$ for $12 \mathrm{~h}$ and $\mathrm{H}_{2} \mathrm{O}_{2}(600 \mu \mathrm{M})$ for $2 \mathrm{~h}$, in a consecutive manner. Total RNA was extracted using TRIzol reagent (Invitrogen; Thermo Fisher Scientific, Inc.) according to the manufacturer's instructions. RNA purity and concentration were evaluated using a MaestroNano ${ }^{\circledR}$ microspectrophotometer (Maestrogen, Las Vegas, NV, USA). Total RNA was reverse transcribed into cDNA using the oiligo $\mathrm{d}(\mathrm{T})_{23}$ primer and ProtoScript First Strand cDNA Synthesis kit (New England BioLabs, Inc., Ipswich, MA, USA) following the manufacturer's instructions. HO-1,SOD1, CAT, SIRT1, TNF- $\alpha$ and IL- 6 mRNA expression levels were evaluated using $5 \mathrm{x}$ HOT FIREPOL ${ }^{\circledR}$ EvaGreen ${ }^{\circledR}$ qPCR mix (Solis BioDyne, Tartu, Estonia), a StepOnePlus Real-Time PCR system (Applied Biosystems; Thermo Fisher Scientific, Inc.) and gene-specific primers. Each thermo-cycling condition was same in denaturation $\left(95^{\circ} \mathrm{C}\right)$ and extension $\left(72^{\circ} \mathrm{C}\right)$, except the annealing temperature which differed when different primers were used. The $\mathrm{Cq}$ value associated with each gene was normalized to the expression of the $\beta$-actin housekeeping gene. The sequences of the qPCR primers are provided in Table I. The $2^{-\Delta \Delta \mathrm{Cq}}$ method (29) was used to calculate the relative expression levels of each gene.

Analysis of luciferase reporter gene activity. Transcriptional activity of NRF2 was determined using an antioxidant ARE Reporter kit (cat. no. 60514; BPS Bioscience, San Diego, CA, USA). The luciferase activity was quantitatively assessed according to the manufacturer's instructions. Briefly, NHDFs were cotransfected with NRF2-ARE-luciferase reporter plasmid (BPS Bioscience) and a plasmid that constitutively expressed Renilla luciferase using Lipofectamine ${ }^{\mathrm{TM}} 2000$ (Invitrogen; Thermo Fisher Scientific, Inc.). The transfection was conducted according to the manufacturer's instructions with some modifications. The Lipofectamine reagent was mixed with serum-free Opti-MEM (Invitrogen; Thermo Fisher Scientific, Inc.) for $5 \mathrm{~min}$, and then added to the plasmid with gently flicking for $20 \mathrm{~min}$, at room temperature. The transfection mixture was added to the cells and incubated at $37^{\circ} \mathrm{C}$. After $24 \mathrm{~h}$ of transfection, cells were pretreated for $12 \mathrm{~h}$ with the indicated doses of RA $(10,20$ and $30 \mu \mathrm{M})$, and were then exposed to $600 \mu \mathrm{M} \mathrm{H}_{2} \mathrm{O}_{2}$ for $2 \mathrm{~h}$. The cells were re-suspended in Passive lysis buffer (Promega Corporation) and luciferase activity was measured using a Dual-Luciferase Reporter Assay system (Promega Corporation). The luciferase activity of ARE was normalized to Renilla luciferase activity.

Statistical analysis. All results are presented as the mean \pm standard deviation of three independent experiments. Statistical analysis was performed using SPSS software version 17.0 (SPSS, Inc., Chicago, IL, USA). One-way analysis of variance followed by Tukey post hoc test was conducted for multiple comparisons. $\mathrm{P}<0.05$ was considered to indicate a statistically significant difference.

\section{Results}

$R A$ reduces $\mathrm{H}_{2} \mathrm{O}_{2}$-induced cytotoxicity in NHDFs. The present study initially determined the dose range of RA that was not markedly cytotoxic to NHDFs. The cells were treated with increasing concentrations of RA $(0-50 \mu \mathrm{M})$ for $12 \mathrm{~h}$. Concentrations of $\mathrm{RA}<50 \mu \mathrm{M}$ were not were not significantly cytotoxic; therefore, 10-30 $\mu \mathrm{M}$ RA was used for subsequent experiments. To determine if RA affects the viability of NHDFs exposed to $\mathrm{H}_{2} \mathrm{O}_{2}$-induced cellular stress, NHDFs were sequentially treated with RA and $\mathrm{H}_{2} \mathrm{O}_{2}$, and cytotoxicity was evaluated using a WST-1 assay. As presented in Fig. 1, cell viability decreased to $76 \%$ of the control in cells treated with $600 \mu \mathrm{M} \mathrm{H}_{2} \mathrm{O}_{2}$ for $12 \mathrm{~h}$. Pretreatment with 10-30 $\mu \mathrm{M}$ RA for $12 \mathrm{~h}$ significantly inhibited $\mathrm{H}_{2} \mathrm{O}_{2}$-induced cytotoxicity (Fig. 1B).

RA inhibits $\mathrm{H}_{2} \mathrm{O}_{2}$-mediated induction of $\mathrm{SA}$ - $\beta$-gal activity in NHDFs. $\mathrm{H}_{2} \mathrm{O}_{2}$-mediated ROS activates endogenous cellular responses to oxidative stress (30). However, when this defense system collapses, superoxide anion, hydroxyl radical and singlet oxygen production induces cellular senescence and apoptosis (31-33). In the present study, $\mathrm{H}_{2} \mathrm{O}_{2}$ induced cellular senescence in NHDFs, as demonstrated by an SA- $\beta$-gal assay (Fig. 2). Notably, RA markedly inhibited cellular senescence in a concentration-dependent manner in $\mathrm{H}_{2} \mathrm{O}_{2}$-exposed 
A

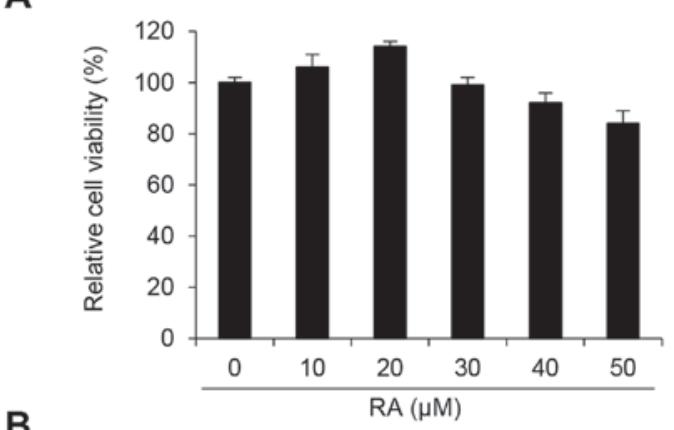

B

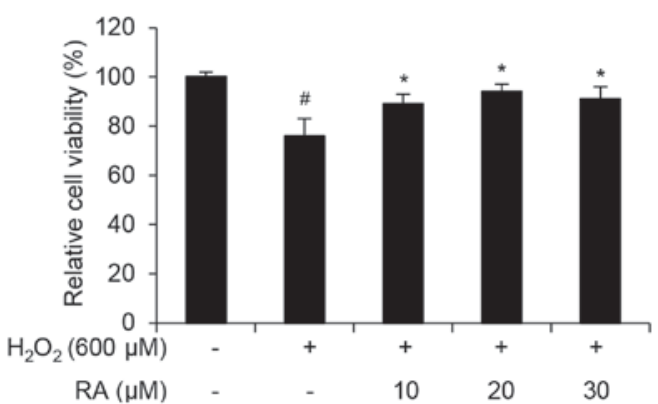

Figure 1. Protective effects of RA against $\mathrm{H}_{2} \mathrm{O}_{2}$ in NHDFs. (A) Evaluation of cytotoxicity in RA-treated NHDFs. Following $12 \mathrm{~h}$ of RA treatment, cell viability was evaluated using a water-soluble tetrazolium salt-based cytotoxicity assay. (B) RA mediated protective effects against $\mathrm{H}_{2} \mathrm{O}_{2}$ cytotoxicity in NHDFs. Cells were pretreated with varying doses of RA for $12 \mathrm{~h}$ prior to exposure to $600 \mu \mathrm{M} \mathrm{H}_{2} \mathrm{O}_{2}$. Data are presented as the mean \pm standard deviation of relative cell viability from triplicate experiments. ${ }^{\#} \mathrm{P}<0.05$ compared with non-treated control cells; ${ }^{*} \mathrm{P}<0.05$ compared with $\mathrm{H}_{2} \mathrm{O}_{2}$-treated cells. $\mathrm{H}_{2} \mathrm{O}_{2}$, hydrogen peroxide; NHDFs, normal human dermal fibroblasts; RA, rosmarinic acid.

NHDFs (Fig. 2), thus suggesting that RA protects NHDFs from $\mathrm{H}_{2} \mathrm{O}_{2}$-mediated induction of SA- $\beta$-gal activity.

RA inhibits $\mathrm{H}_{2} \mathrm{O}_{2}$-induced oxidative stress in $\mathrm{NHDFs}$. Similar to previous studies, the present study investigated whether the protective effects of RA were associated with its oxidative properties (23-25). To evaluate the ROS scavenging activity of RA, $\mathrm{H}_{2} \mathrm{O}_{2}$ scavenging activity, DCF-DA fluorescence intensity, NRF2 activity and the expression of genes that regulate oxidative stress (HO-1, SODl and CAT) were assessed. RA showed an increase in $\mathrm{H}_{2} \mathrm{O}_{2}$ scavenging activity and ascorbic acid was used as positive control (Fig. 3A). Although the free radical scavenging activity of RA was less than the positive control (L-ascorbic acid), the half maximal inhibitory concentration of RA was $0.56 \mathrm{mg} / \mathrm{ml}$, and the radical scavenging activity of RA occurred in a dose-dependent manner. DCF fluorescence intensity, which is an indicator of intracellular ROS levels, was evaluated in RA-pretreated NHDFs with or without $\mathrm{H}_{2} \mathrm{O}_{2}$ exposure. DCF intensity increased $>8$-fold in $\mathrm{H}_{2} \mathrm{O}_{2}$-exposed cells compared with the nonexposed control group (Fig. 2B). However, this effect was strongly reduced in NHDFs pretreated with either RA or the positive control antioxidant NAC (Fig. 3B). NRF2 serves a key role in the regulation of antioxidant mechanisms by activating the transcription of genes encoding antioxidant enzymes, including HO-l, SODI and CAT, via the ARE in the target gene promoter (5-7). Therefore, the present study analyzed the transcriptional activity of NRF2 using the ARE-luciferase assay.

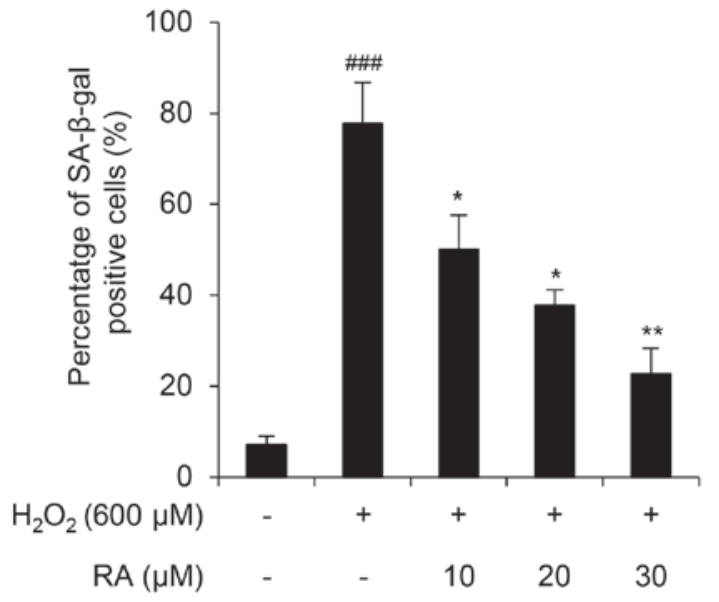

Figure 2. Protective effects of RA against $\mathrm{H}_{2} \mathrm{O}_{2}$-mediated SA- $\beta$-gal activation in NHDFs. Cells were pretreated with the indicated doses of RA for $12 \mathrm{~h}$ prior to exposure to $600 \mu \mathrm{M} \mathrm{H}_{2} \mathrm{O}_{2}$ for $48 \mathrm{~h}$. Cellular senescence was evaluated using an SA- $\beta$-gal assay. Data are presented as the mean \pm standard deviation from triplicate experiments. ${ }^{\# \#} \mathrm{P}<0.001$ compared with non-treated control cells; ${ }^{*} \mathrm{P}<0.05,{ }^{* *} \mathrm{P}<0.01$ compared with $\mathrm{H}_{2} \mathrm{O}_{2}$-treated cells. $\mathrm{H}_{2} \mathrm{O}_{2}$, hydrogen peroxide; NHDFs, normal human dermal fibroblasts; RA, rosmarinic acid; SA- $\beta$-gal, senescence-associated $\beta$-galactosidase.

As presented in Fig. 3C, RA markedly enhanced luciferase activity in a concentration-dependent manner, thus suggesting that RA activates NRF2 activity in NHDFs. In addition, the expression levels of the NRF2 target genes, $H O-1, S O D 1$ and $C A T$, were detected. Notably, RA markedly upregulated the target genes against $\mathrm{H}_{2} \mathrm{O}_{2}$-induced oxidative stress (Fig. 3D). These results suggested that RA exerts a protective effect on $\mathrm{H}_{2} \mathrm{O}_{2}$-induced oxidative stress in NHDFs via NRF2-associated antioxidant mechanisms.

$\mathrm{RA}$ inhibits the $\mathrm{H}_{2} \mathrm{O}_{2}$-induced inflammatory response in NHDFs. The mammalian Sir2 ortholog, SIRT1, is a histone deacetylase that targets histones and nonhistone substrates, including NF- $\mathrm{KB}$ and $\mathrm{p} 53(8,9,34)$. Previous studies have demonstrated that SIRT1 is involved in the regulation of numerous cellular processes, including inflammation, apoptosis and autophagy, and that SIRT1 expression is downregulated in response to oxidative stress $(10-12,35)$. Therefore, the present study evaluated the expression levels of SIRT1 and various inflammatory cytokines, including NF- $\kappa B$, TNF- $\alpha$ and IL- 6 in NHDFs. SIRT1 levels were decreased in NHDFs exposed to $600 \mu \mathrm{M} \mathrm{H}_{2} \mathrm{O}_{2}$, whereas RA inhibited this effect in a concentration-dependent manner (Fig. 4A). To determine the effects of $\mathrm{H}_{2} \mathrm{O}_{2}$ and RA on NF- $\kappa \mathrm{B}$ expression, an NF- $\mathrm{KB}$ luciferase reporter stable NIH-3T3 cell line was used. As presented in Fig. 4B, relative luciferase activity in $\mathrm{H}_{2} \mathrm{O}_{2}$-exposed NHDFs increased 5.71 \pm 0.42 -fold compared with the control group $(\mathrm{P}<0.05)$. Notably, pretreatment with 20 and $30 \mu \mathrm{M}$ RA significantly inhibited this effect $(\mathrm{P}<0.05)$. To further evaluate the effects of $\mathrm{H}_{2} \mathrm{O}_{2}$ and RA on the activity of $\mathrm{NF}-\kappa \mathrm{B}$, the expression levels of the NF- $\mathrm{KB}$ target genes, $T N F-\alpha$ and $I L-6$, were determined. $\mathrm{H}_{2} \mathrm{O}_{2}$ upregulated $T N F-\alpha$ and $I L-6$ expression, whereas RA significantly inhibited this effect in a concentration-dependent manner (Fig. 4C). Taken together, these results indicated that RA exerts an anti-inflammatory effect on NHDFs under conditions of excessive oxidative stress. 
A

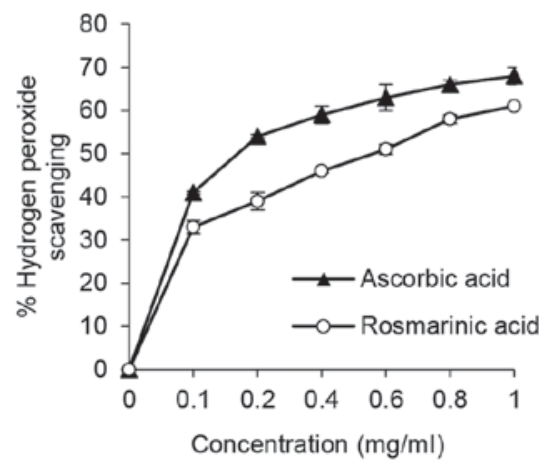

C

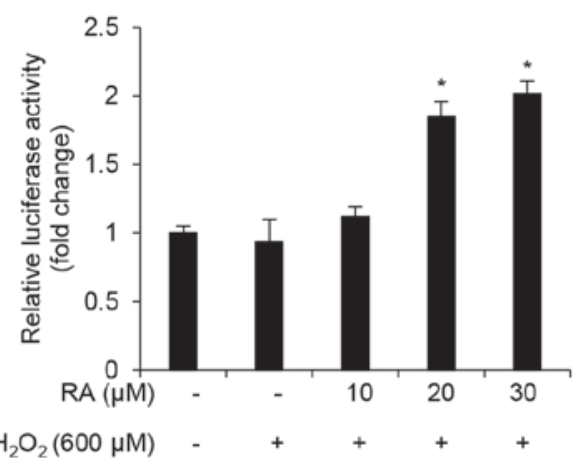

B

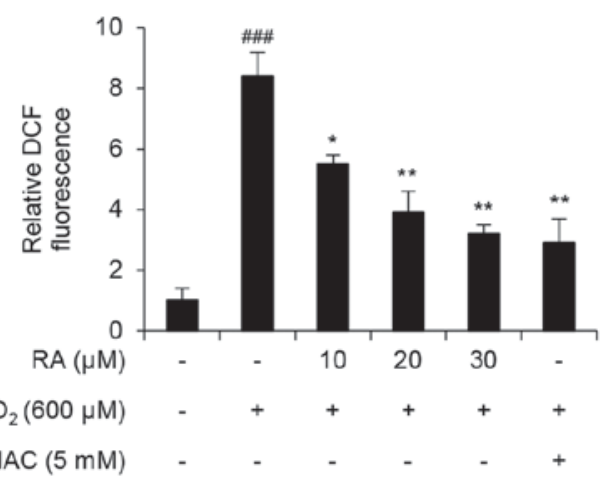

D

\section{- Control}

$\square \mathrm{H}_{2} \mathrm{O}_{2}(600 \mu \mathrm{M})$

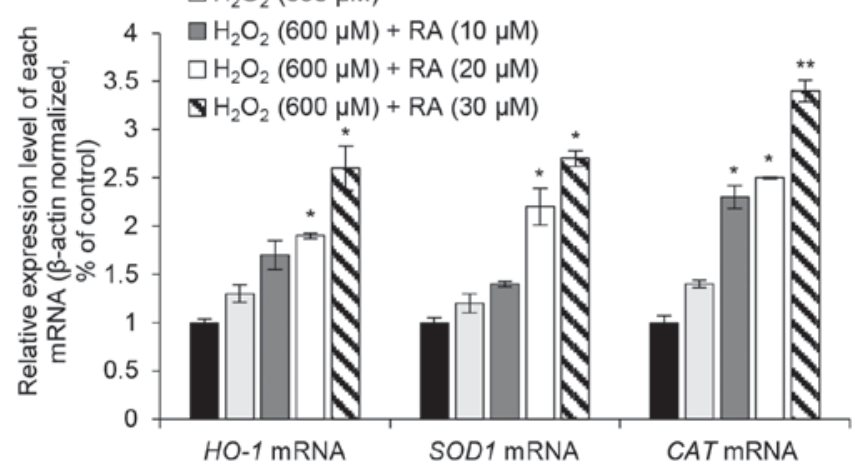

Figure 3. Antioxidative effects of RA in $\mathrm{H}_{2} \mathrm{O}_{2}$-exposed NHDFs. (A) $\mathrm{H}_{2} \mathrm{O}_{2}$ scavenging activity of $\geq 1 \mathrm{mg} / \mathrm{ml} \mathrm{RA}$. L-ascorbic acid was used as the positive control. (B) Intracellular ROS scavenging activity of RA in $\mathrm{H}_{2} \mathrm{O}_{2}$-exposed NHDFs. NAC was used as the positive control. (C) Effects of RA on nuclear factor erythroid-derived 2-like 2 transcriptional activity in $\mathrm{H}_{2} \mathrm{O}_{2}$-treated NHDFs. Transcriptional activity was evaluated using an antioxidant response element-luciferase reporter assay. (D) Effects of RA on the expression of antioxidant genes in $\mathrm{H}_{2} \mathrm{O}_{2}$-exposed NHDFs. HO-1, SOD1 and CAT mRNA expression levels were evaluated using quantitative polymerase chain reaction. Data are presented as the mean \pm standard deviation from triplicate experiments. ${ }^{\# \# \#} \mathrm{P}<0.001$ compared with non-treated control cells; ${ }^{*} \mathrm{P}<0.05,{ }^{* * *} \mathrm{P}<0.01$ compared with $\mathrm{H}_{2} \mathrm{O}_{2}$-treated cells. CAT, catalase; DCF, 2'7'-dichlorofluorescein; $\mathrm{H}_{2} \mathrm{O}_{2}$, hydrogen peroxide; HO-1, heme oxygenase-1; NAC, $N$-acetyl-cysteine; NHDFs, normal human dermal fibroblasts; RA, rosmarinic acid; SOD1, superoxide dismutase.

A

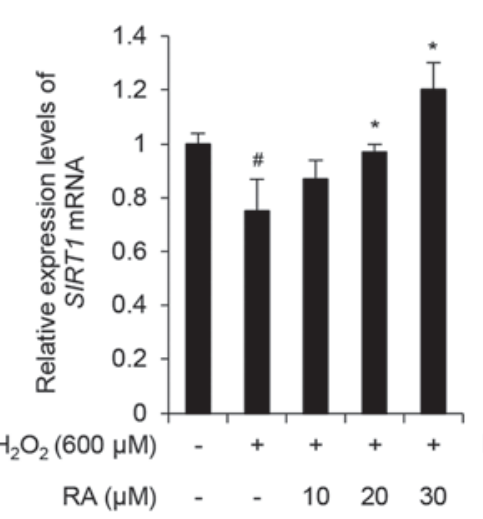

B

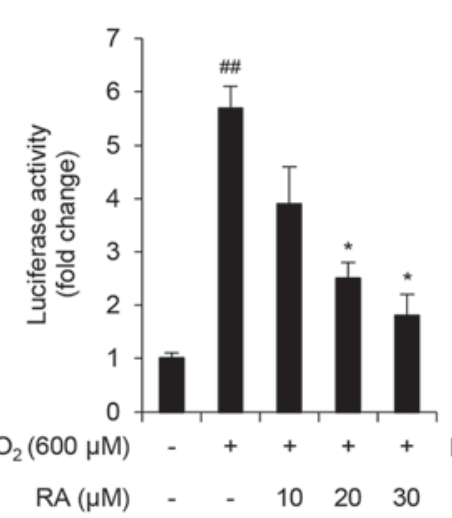

C

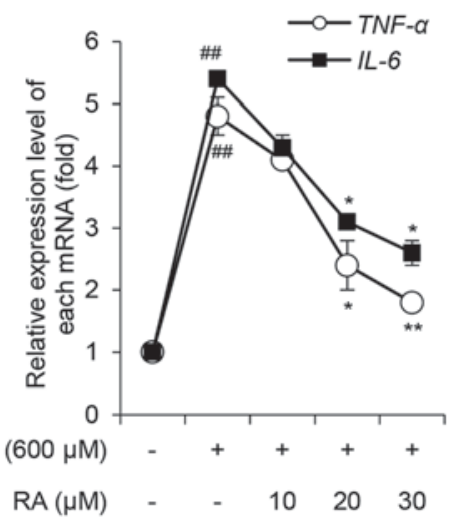

Figure 4. Effects of RA on the $\mathrm{H}_{2} \mathrm{O}_{2}$-induced inflammatory response in NHDFs. (A) Effects of RA on SIRT1 expression in $\mathrm{H}_{2} \mathrm{O}_{2}$-exposed NHDFs. SIRT1

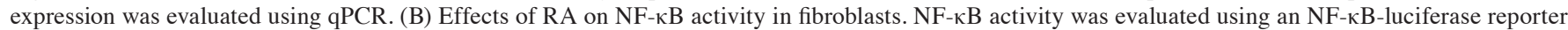
assay. (C) Effects of RA on the expression of genes associated with inflammation in $\mathrm{H}_{2} \mathrm{O}_{2}$-exposed NHDFs. $T N F-\alpha$ and $I L-6$ expression levels were evaluated using qPCR. Data are presented as the mean \pm standard deviation from triplicate experiments. ${ }^{\#} \mathrm{P}<0.05,{ }^{\# \#} \mathrm{P}<0.01$ compared with non-treated control cells; "P $<0.05$, "* $\mathrm{P}<0.01$ compared with $\mathrm{H}_{2} \mathrm{O}_{2}$-treated cells. $\mathrm{H}_{2} \mathrm{O}_{2}$, hydrogen peroxide; $I L$ - 6 , interleukin-6; NF- $\mathrm{kB}$, nuclear factor- $\mathrm{kB}$; NHDFs, normal human dermal fibroblasts; qPCR, quantitative polymerase chain reaction; RA, rosmarinic acid; SIRT1, sirtuin $1 ; T N F-\alpha$, tumor necrosis factor- $\alpha$.

\section{Discussion}

Numerous studies have demonstrated that ROS exist in all living tissues, and are essential for various cellular functions, including epithelial cell proliferation and wound healing (36), and dermal fibroblast migration (37). However, excess ROS can trigger deleterious effects, such as apoptosis and cellular senescence (3). There is a marked decreased in antioxidant levels in aged skin, and treating aged skin with antioxidants, such as resveratrol and vitamin E, can partially rejuvenate 
aged skin (38). These findings suggested that ROS may be the primary cause for the appearance of aging skin. $\mathrm{H}_{2} \mathrm{O}_{2}$ is a type of ROS, which is generated in response to UV light and numerous pollutants (39). The histological alterations in aged skin are markedly visible in the dermis layer, where dermal fibroblasts are the primary cell type (40). In addition, a reduction in CAT activity and an increase in $\mathrm{H}_{2} \mathrm{O}_{2}$ levels have been observed in dermal fibroblasts from aged human skin compared with in dermal fibroblasts from younger human skin (41). In a previous study, treatment with exogenous CAT rescued the reduction in intracellular CAT protein activity and the increase in $\mathrm{H}_{2} \mathrm{O}_{2}$ levels in aged fibroblasts, and also reduced collagenase matrix metalloproteinase 1 expression (41). These data indicated that suppressing $\mathrm{H}_{2} \mathrm{O}_{2}$ generation in dermal fibroblasts may inhibit the skin aging process. Notably, in the present study, $\mathrm{H}_{2} \mathrm{O}_{2}$ exposure strongly enhanced cytotoxicity and SA- $\beta$-gal activity, which are similar to the effects observed in tissues from older individuals (42). However, RA pretreatment markedly protected NHDFs from $\mathrm{H}_{2} \mathrm{O}_{2}$-induced cytotoxicity and SA- $\beta$-gal activation. In addition, the $\mathrm{H}_{2} \mathrm{O}_{2}$ scavenging capacity of RA was investigated, as was the intracellular $\mathrm{H}_{2} \mathrm{O}_{2}$ scavenging capacity of RA in NHDFs. The results demonstrated that RA exhibited substantial $\mathrm{H}_{2} \mathrm{O}_{2}$ scavenging activity and inhibited $\mathrm{H}_{2} \mathrm{O}_{2}$-induced intracellular ROS production. Taken together, these data suggested that RA may be considered a potential ingredient in anti-aging skin products.

The results of the present study prompted the hypothesis that RA may regulate intracellular antioxidant activity in NHDFs. Although RA has exhibited antioxidant activity in keratinocytes $(24,25)$, there are differences in the oxidative stress response between keratinocytes and dermal fibroblasts (43). To test the hypothesis, ARE luciferase assays and RT-qPCR were conducted to evaluate the expression of the antioxidant-induced NRF2 target genes $H O-1, S O D 1$ and $C A T$. RA rescued $\mathrm{H}_{2} \mathrm{O}_{2}$-mediated inhibition of NRF2 transcriptional activity and the consequential decrease in NRF2 target gene expression. Consistent with these findings, a previous study demonstrated that RA inhibits UVB-induced ROS production and the decrease in protein levels encoded by NRF2 target genes in HaCaT keratinocytes (24). In addition, a previous report demonstrated that the NRF2-inducer tanshinone I exerted a protective effect against UV radiation in human skin cells and reconstructed human skin (44). Furthermore, NRF2 depletion induces damage to the extracellular matrix (45), a hallmark of skin aging (46). Taken together, these findings indicated that RA may inhibit $\mathrm{H}_{2} \mathrm{O}_{2}$ via a NRF2-associated antioxidant mechanism in NHDFs.

The present study also demonstrated that RA inhibited the $\mathrm{H}_{2} \mathrm{O}_{2}$-induced inflammatory response in NHDFs. Oxidative stress is associated with inflammation in skin tissue (47), and upregulation of the inflammatory response is associated with numerous skin diseases, including atopic dermatitis and psoriasis (48). SIRT1 serves critical roles in apoptosis, senescence, autophagy, gene silencing and inflammation $(11,12,48,49)$. Under excessive ROS conditions, SIRT1 is inactivated and cannot suppress the activity of NF- $\mathrm{KB}$, which is a protein that serves a key role in inflammatory responses by activating the transcription of proinflammatory cytokines, such as TNF- $\alpha$ and IL-6 (16). In the present study, RA inhibited $\mathrm{H}_{2} \mathrm{O}_{2}$-mediated SIRT1 downregulation in NHDFs, and NF- $\mathrm{KB}$ activity was decreased in RA-treated NHDFs. Furthermore, RA significantly downregulated the expression levels of $T N F-\alpha$ and $I L-6$ in a dose-dependent manner. NF- $\mathrm{kB}$ activation is regarded as a potential biomarker of aging (14); an increase in NF- $\mathrm{kB}$ activity is correlated with tissue aging and age-associated degenerative diseases (15).

In conclusion, the findings of the present study suggested that RA may inhibit senescence and inflammatory responses in NHDFs, which are effects associated with aging skin. To gain insight into the effects of RA on human skin, further studies should focus on the efficacy of RA in reversing the signs of aging skin and evaluate the precise molecular mechanisms by which RA mediates this effect in vivo.

\section{Acknowledgements}

The present study was supported by a grant from the Ministry of Trade, Industry and Energy (MOTIE), Korea Institute for Advancement of Technology (KIAT) through the Encouragement Program for The Industries of Economic Cooperation Region (grant no. R0003962) and a grant from the Marine Biotechnology Program (grant no. 20150184) funded by the Ministry of Oceans and Fishers, Republic of Korea.

\section{References}

1. Poljsak B, Dahmane RG and Godić A: Intrinsic skin aging: The role of oxidative stress. Acta Dermatovenerol Alp Pannonica Adriat 21: 33-36, 2012.

2. Ganceviciene R, Liakou AI, Theodoridis A, Makrantonaki E and Zouboulis CC: Skin anti-aging strategies. Dermatoendocrinol 4: 308-319, 2012.

3. Davalli P, Mitic T, Caporali A, Lauriola A and D'Arca D: ROS, cell senescence, and novel molecular mechanisms in aging and age-related diseases. Oxid Med Cell Longev 2016: 3565127, 2016.

4. Kansanen E, Kuosmanen SM, Leinonen H and Levonen AL: The Keap1-Nrf2 pathway: Mechanisms of activation and dysregulation in cancer. Redox Biol 1: 45-49, 2013.

5. Kensler TW, Wakabayashi $\mathrm{N}$ and Biswal S: Cell survival responses to environmental stresses via the Keap1-Nrf2-ARE pathway. Annu Rev Pharmacol Toxicol 47: 89-116, 2007.

6. Itoh K, Chiba T, Takahashi S, Ishii T, Igarashi K, Katoh Y, Oyake T, Hayashi N, Satoh K, Hatayama I, et al: An Nrf2/small Maf heterodimer mediates the induction of phase II detoxifying enzyme genes through antioxidant response elements. Biochem Biophys Res Commun 236: 313-322, 1997.

7. Buendia I, Michalska P, Navarro E, Gameiro I, Egea J and Leon R: Nrf2-ARE pathway: An emerging target against oxidative stress and neuroinflammation in neurodegenerative diseases. Pharmacol Ther 157: 84-104, 2016.

8. Luo J, Nikolaev AY, Imai S, Chen D, Su F, Shiloh A, Guarente L and $\mathrm{Gu}$ W: Negative control of p53 by Sir2alpha promotes cell survival under stress. Cell 107: 137-148, 2001.

9. Vaziri H, Dessain SK, Ng Eaton E, Imai SI, Frye RA, Pandita TK, Guarente L and Weinberg RA: hSIR2(SIRT1) functions as an NAD-dependent p53 deacetylase. Cell 107: 149-159, 2001.

10. Wu A, Ying $\mathrm{Z}$ and Gomez-Pinilla F: Oxidative stress modulates Sir2alpha in rat hippocampus and cerebral cortex. Eur J Neurosci 23: 2573-2580, 2006.

11. Moon MH, Jeong JK, Lee YJ, Seol JW, Jackson CJ and Park SY: SIRT1, a class III histone deacetylase, regulates TNF- $\alpha$-induced inflammation in human chondrocytes. Osteoarthritis Cartilage 21: 470-480, 2013.

12. Takayama K, Ishida K, Matsushita T, Fujita N, Hayashi S, Sasaki K, Tei K, Kubo S, Matsumoto T and Fujioka H: SIRT1 regulation of apoptosis of human chondrocytes. Arthritis Rheum 60: 2731-2740, 2009.

13. Salminen A, Kauppinen A, Suuronen T and Kaarniranta K: SIRT1 longevity factor suppresses NF-kappaB-driven immune responses: Regulation of aging via NF-kappaB acetylation? Bioessays 30: 939-942, 2008. 
14. Balistreri CR, Candore G, Accardi G, Colonna-Romano G and Lio D: NF- $\mathrm{kB}$ pathway activators as potential ageing biomarkers: Targets for new therapeutic strategies. Immun Ageing 10: 24, 2013

15. Tilstra JS, Clauson CL, Niedernhofer LJ and Robbins PD: NF- $\kappa B$ in Aging and Disease. Aging Dis 2: 449-465, 2011.

16. Tak PP and Firestein GS: NF-kappaB: A key role in inflammatory diseases. J Clin Invest 107: 7-11, 2001.

17. Vladimir-Knezevic S, Blazekovic B, Kindl M, Vladic J, Lower-Nedza AD and Brantner AH: Acetylcholinesterase inhibitory, antioxidant and phytochemical properties of selected medicinal plants of the Lamiaceae family. Molecules 19: 767-782, 2014

18. Jang AH, Kim TH, Kim GD, Kim JE, Kim HJ, Kim SS, Jin YH, Park YS and Park CS: Rosmarinic acid attenuates 2,4-dinitrofluorobenzene-induced atopic dermatitis in NC/Nga mice. Int Immunopharmacol 11: 1271-1277, 2011.

19. Karthik D, Viswanathan P and Anuradha CV: Administration of rosmarinic acid reduces cardiopathology and blood pressure through inhibition of p22phox NADPH oxidase in fructose-fec hypertensive rats. J Cardiovasc Pharmacol 58: 514-521, 2011.

20. Kim GD, Park YS, Jin YH and Park CS: Production and applications of rosmarinic acid and structurally related compounds Appl Microbiol Biotechnol 99: 2083-2092, 2015.

21. Khojasteh A, Mirjalili MH, Hidalgo D, Corchete P and Palazon J: New trends in biotechnological production of rosmarinic acid. Biotechnol Lett 36: 2393-2406, 2014.

22. Sanchez-Campillo M, Gabaldon JA, Castillo J, Benavente-García O, Del Baño MJ, Alcaraz M, Vicente V, Alvarez N and Lozano JA: Rosmarinic acid, a photo-protective agent against UV and other ionizing radiations. Food Chem Toxicol 47: 386-392, 2009.

23. Yoo SM and Kang JR: Antioxidation effects of rosmarinic acid on human skin melanoma cells treated with hydrogen peroxide. J Korean Soc Appl Bi 52: 247-251, 2009.

24. Fernando PM, Piao MJ, Kang KA, Ryu YS, Hewage SR, Chae SW and Hyun JW: Rosmarinic acid attenuates cell damage against UVB radiation-induced oxidative stress via enhancing antioxidant effects in human HaCaT cells. Biomol Ther (Seoul) 24 $75-84,2016$.

25. Vostálová J, Zdarilová A and Svobodová A: Prunella vulgaris extract and rosmarinic acid prevent UVB-induced DNA damage and oxidative stress in HaCaT keratinocytes. Arch Dermatol Res 302: 171-181, 2010.

26. Oyedemi SO, Bradley G and Afolayan AJ: In-vitro and -vivo antioxidant activities of aqueous extract of Strychnos henningsi Gilg. Afr J Pharm Pharmaco 4: 70-78, 2010.

27. Martinez-Outschoorn UE, Trimmer C, Lin Z, Whitaker-Menezes D, Chiavarina B, Zhou J, Wang C, Pavlides S, Martinez-Cantarin MP, Capozza F, et al: Autophagy in cancer associated fibroblasts promotes tumor cell survival: Role of hypoxia, HIF1 induction and $\mathrm{NF \kappa B}$ activation in the tumor stromal microenvironment. Cell Cycle 9: 3515-3533, 2010.

28. Debacq-Chainiaux F, Erusalimsky JD, Campisi J and Toussaint O: Protocols to detect senescence-associated beta-galactosidase (SA-betagal) activity, a biomarker of senescent cells in culture and in vivo. Nat Protoc 4: 1798-1806, 2009.

29. Livak KJ and Schmittgen TD: Analysis of relative gene expression data using real-time quantitative PCR and the 2(-Delta Delta C(T)) method. Methods 25: 402-408, 2001.

30. Martindale JL and Holbrook NJ: Cellular response to oxidative stress: Signaling for suicide and survival. J Cell Physiol 192: $1-15,2002$.

31. Korycka-Dahl MB and Richardson T: Activated oxygen species and oxidation of food constituents. CRC Crit Rev Food Sci Nutr 10: 209-241, 1978

32. Halliwell B and Gutteridge JM: Oxygen free radicals and iron in relation to biology and medicine: Some problems and concepts Arch Biochem Biophys 246: 501-514, 1986.
33. Simon HU, Haj-Yehia A and Levi-Schaffer F: Role of reactive oxygen species (ROS) in apoptosis induction. Apoptosis 5: 415-418, 2000

34. Yeung F, Hoberg JE, Ramsey CS, Keller MD, Jones DR, Frye RA and Mayo MW: Modulation of NF-kappaB-dependent transcription and cell survival by the SIRT1 deacetylase. EMBO J 23: 2369-2380, 2004.

35. Ou X, Lee MR, Huang X, Messina-Graham S and Brox meyer HE: SIRT1 positively regulates autophagy and mitochondria function in embryonic stem cells under oxidative stress. Stem Cells 32: 1183-1194, 2014

36. Huo Y, Qiu WY, Pan Q, Yao YF, Xing K and Lou MF: Reactive oxygen species (ROS) are essential mediators in epidermal growth factor (EGF)-stimulated corneal epithelial cell proliferation, adhesion, migration, and wound healing. Exp Eye Res 89: 876-886, 2009.

37. Shi HX, Cheng Y, Ye JJ, Cai P, Zhang J, Li R, Yang Y, Wang Z, Zhang $\mathrm{H}$, Lin $\mathrm{C}$, et al: bFGF promotes the migration of human dermal fibroblasts under diabetic conditions through reactive oxygen species production via the PI3K/Akt-Rac1-JNK pathways. Int J Biol Sci 11: 845-859, 2015.

38. Farris P, Yatskayer M, Chen N, Krol Y and Oresajo C: Evaluation of efficacy and tolerance of a nighttime topical antioxidant containing resveratrol, baicalin, and vitamin e for treatment of mild to moderately photodamaged skin. J Drugs Dermatol 13: 1467-1472, 2014

39. Peus D, Vasa RA, Meves A, Pott M, Beyerle A, Squillace K and Pittelkow MR: $\mathrm{H}_{2} \mathrm{O}_{2}$ is an important mediator of UVB-induced EGF-receptor phosphorylation in cultured keratinocytes. J Invest Dermatol 110: 966-971, 1998.

40. Gilchrest BA: Skin aging and photoaging: An overview. J Am Acad Dermatol 21: 610-613, 1989.

41. Shin $\mathrm{MH}$, Rhie GE, Kim YK, Park $\mathrm{CH}$, Cho KH, Kim KH, Eun $\mathrm{HC}$ and Chung $\mathrm{JH}: \mathrm{H}_{2} \mathrm{O}_{2}$ accumulation by catalase reduction changes MAP kinase signaling in aged human skin in vivo. J Invest Dermatol 125: 221-229, 2005.

42. Lee BY, Han JA, Im JS, Morrone A, Johung K, Goodwin EC, Kleijer WJ, DiMaio D and Hwang ES: Senescence-associated beta-galactosidase is lysosomal beta-galactosidase. Aging Cell 5: 187-195, 2006.

43. Marionnet C, Pierrard C, Lejeune F, Sok J, Thomas M and Bernerd F: Different oxidative stress response in keratinocytes and fibroblasts of reconstructed skin exposed to non extreme daily-ultraviolet radiation. PLoS One 5: e12059, 2010

44. Tao S, Justiniano R, Zhang DD and Wondrak GT: The Nrf2-inducers tanshinone I and dihydrotanshinone protect human skin cells and reconstructed human skin against solar simulated UV. Redox Biol 1: 532-541, 2013.

45. Saw CL, Yang AY, Huang MT, Liu Y, Lee JH, Khor TO, Su ZY, Shu L, Lu Y, Conney AH and Kong AN: Nrf2 null enhances UVB-induced skin inflammation and extracellular matrix damages. Cell Biosci 4: 39, 2014.

46. Panich U, Sittithumcharee G, Rathviboon N and Jirawatnotai S: Ultraviolet radiation-induced skin aging: The role of DNA damage and oxidative stress in epidermal stem cell damage mediated skin aging. Stem Cells Int 2016: 7370642, 2016.

47. Wagener FA, Carels CE and Lundvig DM: Targeting the redox balance in inflammatory skin conditions. Int J Mol Sci 14: 9126-9167, 2013

48. Rahman I, Kinnula VL, Gorbunova V and Yao H: SIRT1 as a therapeutic target in inflammaging of the pulmonary disease. Prev Med 54 (Suppl): S20-S28, 2012.

49. Yao $\mathrm{H}$ and Rahman I: Perspectives on translational and therapeutic aspects of SIRT1 in inflammaging and senescence. Biochem Pharmacol 84: 1332-1339, 2012. 